\title{
Validity of Existing Rain Water Harvesting Dams within Part of Western Desert, Iraq
}

\author{
Khaldoon Khaled Alwan1, Manal Shakir Ali Al-Kubaisi', Nadhir Al-Ansari2 ${ }^{*}$ \\ ${ }^{1}$ Department of Geology, College of Science, University of Baghdad, Iraq \\ ${ }^{2}$ Department of Civil, Environmental and Natural Resources, Luleå University of Technology, Luleå, Sweden \\ Email: Iraq.khalidkhaldoon@yahoo.com, Manalshakir@scbaghdad.edu.iq, *nadhir.alansari@ltu.se
}

How to cite this paper: Alwan, K.K., Al-Kubaisi, M.S.A. and Al-Ansari, N. (2019) Validity of Existing Rain Water Harvesting Dams within Part of Western Desert, Iraq. Engineering, 11, 806-818.

https://doi.org/10.4236/eng.2019.1112055

Received: November 9, 2019

Accepted: November 23, 2019

Published: November 26, 2019

Copyright $\odot 2019$ by author(s) and Scientific Research Publishing Inc. This work is licensed under the Creative Commons Attribution International License (CC BY 4.0).

http://creativecommons.org/licenses/by/4.0/

\section{(c) (i) Open Access}

\begin{abstract}
The study area is located within the western part of Iraq between Latitude $\left(32^{\circ} 45^{\prime} 0^{\prime \prime}-34^{\circ} 0^{\prime} 0^{\prime \prime}\right)$ North and longitude $\left(39^{\circ} 30^{\prime} 0^{\prime \prime}-40^{\circ} 45^{\prime} 0^{\prime \prime}\right)$ East within Anbar Governorate. It covers an area of $4767.423 \mathrm{Km}^{2}$ with elevation ranges from 360 to $840 \mathrm{~m}$. The general slope decreases from southwest to northeast. Five old dams identified in the study area. The results of SWAT model showed high curve number (70 - 85) indicating low filtration and runoff rate (1.2 - 8.2) $\mathrm{mm}$ for the period (1994-2014). These dams have catchment areas ranged between $(118.03-673.41) \mathrm{km}^{2}$. They were to be used for agricultural purposes. The results according to the Food, Agriculture Organization (FAO) standards for their distance from agricultural areas using a GIS showed that all are not suitable except dam number (1). The distance to roads showed that dams $(1,4)$ are highly suitable, $(2,3)$ are low suitable and dam (5) is not suitable. The average annual quantity of rain water that can be harvested from the 5 dams is about 12.9 million cubic meters.
\end{abstract}

\section{Keywords}

Anbar, Runoff, Suitability, SWAT Mode

\section{Introduction}

The Middle East is considered as an arid and semi-arid region where annual rainfall does not exceed $166 \mathrm{~mm}$ [1]. Iraq was an exception until the 1970s [2] due to the presence of the two main rivers (Tigris and Euphrates). Recently, Iraq is experiencing a water shortage problem. This is due to climate change and the construction of dams and irrigation projects within the upper parts of the catchment of these rivers [3]. This fact requires careful water resources management strategies to overcome the water shortage problem. The use of non-con- 
ventional water resources might be one of the solutions to be used. The major water consumer is agriculture in the Middle East [1].

Water harvesting is defined as the technique used to capture and store rainwater and floods in periods of fall in ways that fall behind different purposes of collection and precipitation rates and reuse, whether for drinking or supplementary irrigation and full or to feed groundwater [4].

The study of water harvesting is very important, especially by building dams in suitable selected locations. This is to take into consideration the necessary information about the geology, topography and the environment. One common reason for low adoption of improved land and water management practices is that the lack of systematic data on potential areas and appropriate locations.

The purpose of this study is to assess the validity of the dams established in the study area to determine their suitability for rainwater harvesting (RWH). The SWAT (Soil Water Assessment Tool) was used to determine the (Curve Number) CN and surface runoff of the area. To find out the suitability map for the water harvesting within the study area the input layers/factors were: rainfall, soil hydrology texture, drainage density, slope, stream order, and land use/land cover. This is due to the fact that determination of the suitability of the land for potential runoff harvesting is site-specific and needs quantitative data and suggests integration of specific factors [5]. All processes for the creation of a suitable rainwater harvesting map were applied during an appropriate model developed in Arc GIS 10.3. The appropriate model creates rainwater harvesting compatibility maps by merging totally different criteria employing a weighted combination process [6]. Dam sites have been assessed in terms of their distance from agricultural areas and roads, according to FAO. The success of RWH systems depends to a great degree on the identification of suitable sites [7] that were evaluated through this study.

\section{Study Area}

The study area is located within the western part of Iraq between Latitude $\left(32^{\circ} 45^{\prime} 0^{\prime \prime}-34^{\circ} 0^{\prime} 0^{\prime \prime}\right)$ North and longitude $\left(39^{\circ} 30^{\prime} 0^{\prime \prime}-40^{\circ} 45^{\prime} 0^{\prime \prime}\right)$ East (Figure 1) at Anbar Governorate. It covers an area of $4767.423 \mathrm{Km}^{2}$ with elevation ranges from 360 to $840 \mathrm{~m}$. The elevation of the study area decreases from southwest to northeast. The climate of the study areas is characterized by hot, dry summer, cold winter and a nice spring and fall. About a ninetieth of the annual precipitation takes place during November to April (most of it within the winter months from December to March). The remaining six months are dry and hot [8]. The oldest exposed rocks within the area are of early-late Permian (Ga'ara Formation), whereas the youngest are Early Miocene (Ghar Formation) [9].

\section{Materials and Methods}

A Digital Elevation Model (DEM) is a specialized database that represents the relief of a surface between points of known elevation; DEMs are wide utilized in 


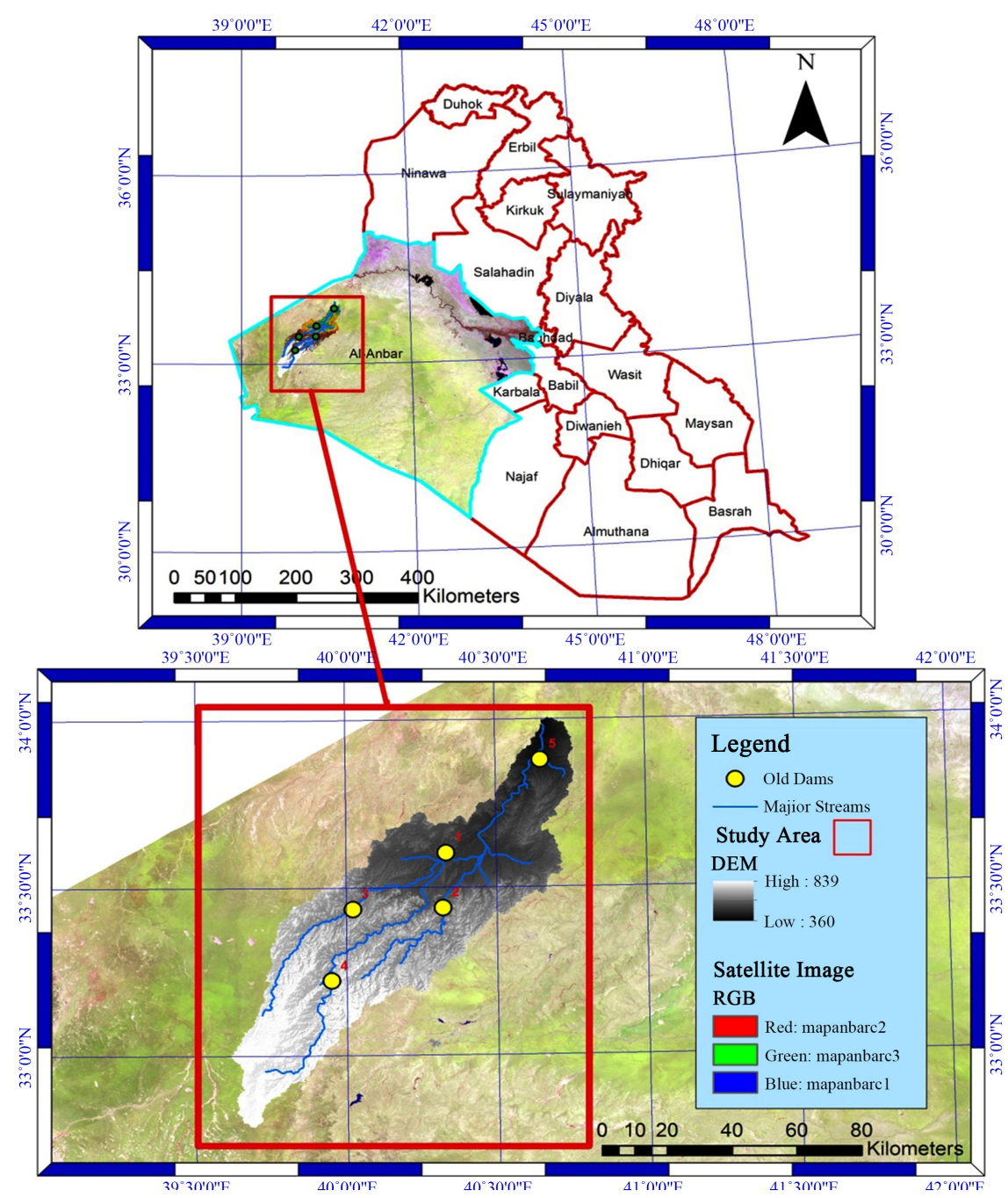

Figure 1. Study area.

hydrologic and earth science analyses, hazard monitoring, natural resources exploration, agricultural management, etc. [10]. It is used to calculate slope, drainage line catchment area. LANDSAT 8 satellite image was used for land uselland cover map. Weather database stores daily weather information for five totally different weather variables relative humidity, precipitation, solar radiation, maximum and Minimum temperature, wind speed and soil map were used also.

To create the suitability map for water harvesting sites, the input layers/factors of rainfall, soil hydrology texture, drainage density, slope, and land use/cover were used (Figure 2). These thematic layers were used to determine the spatial extent of potential surface to identify potential sites for various surface rainwater harvest technologies within the catchment area. Since the determination of the suitability of the land for potential runoff harvesting is site specific and needs quantitative data and suggests integration of specific factors [11].

Using land \water index Bands (5-6-4) five old dams were identified. And by using Arc Hydro tools the stream orders and catchment area for each dam were calculated (Figure 3). 


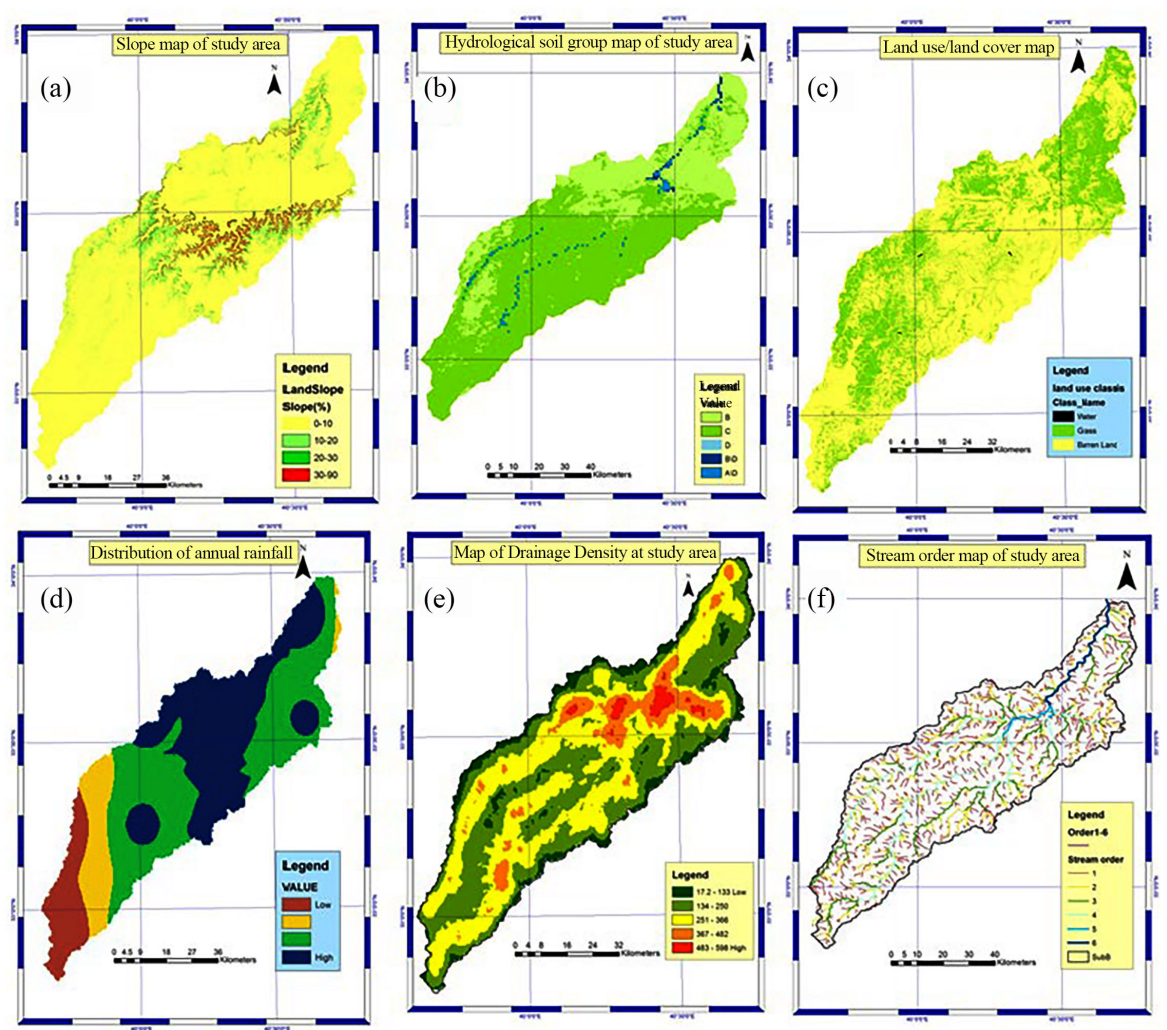

Figure 2. Input variables: (a) slop map; (b) hydrological soil map; (c) land use/cover map; (d) average annual rainfall map; (e) drainage density map; (f) stream order map.
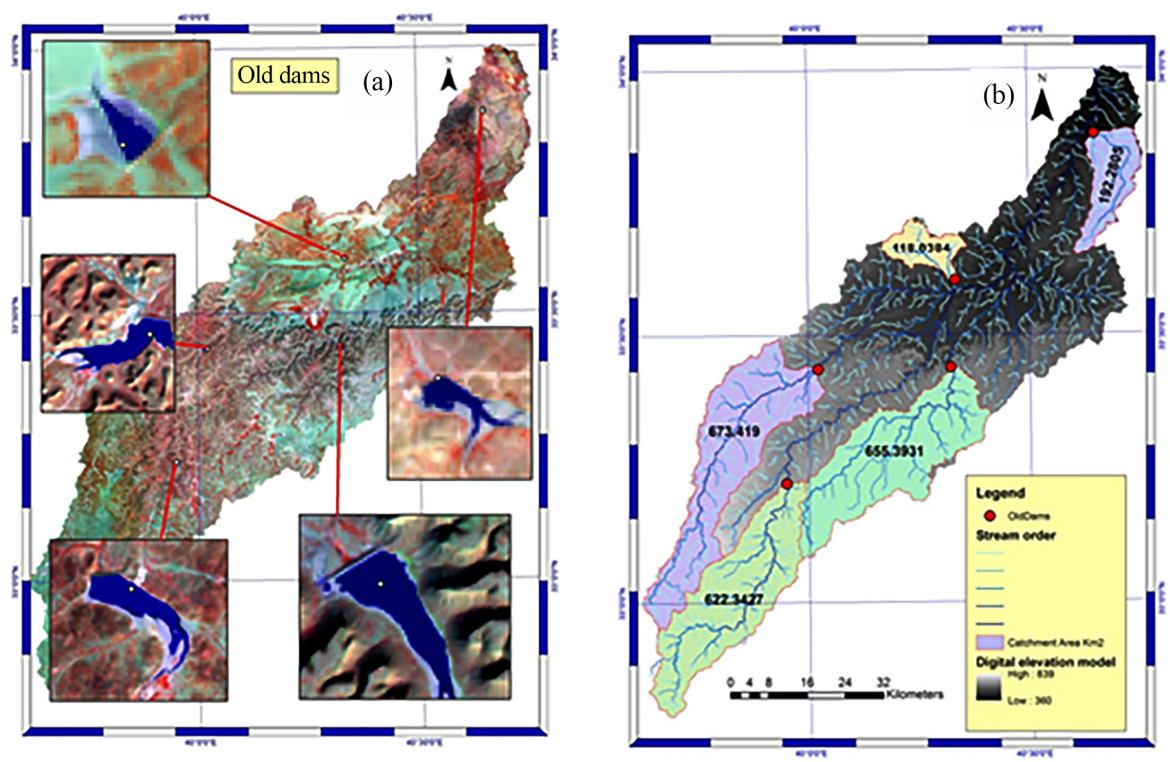

Figure 3. (a) old dams located at study area; (b) stream order and catchment area.

\subsection{SWAT Model}

The SWAT model is a distributed, physics-based and continuous model that is used to perform simulations at catchment scale [12]. It is a hydrology model with the subsequent components: surface runoff, weather, evapotranspiration, and 
transmission losses (Figure 4). The Soil and Water Assessment Tool (SWAT) was developed by the USDA Agricultural research Service (USDA-ARS). SWAT is a simulation model operational on a daily time step. It had been developed to simulate land management processes and rainfall-runoff processes with a high level of spatial detail by permitting the watershed to be divided into sub basins. Every sub basin is divided into many land use and soil type combinations, known as hydrologic response units (HRUs) [13]. The sub basin simulation processes of SWAT comprise major elements like hydrology, erosion, climate and agricultural management. SWAT needs spatial data to appear for the Digital Elevation Model (DEM), soil map, and the land cover of the catchment, as well as meteorological data [14]. In this study SWAT model was used to calculate $\mathrm{CN}$ number and runoff for study area.

\subsection{Curve Number $(\mathrm{CN})$}

$\mathrm{CN}$ method is widely used to estimate the surface runoff from a given precipitation event. CN method has been adopted for this study to estimate the runoff depth. Land cover/land use map and soil map, were accustomed derive curve numbers that were used to estimate runoff depth of the study area. It ranges between 1 (where there's $100 \%$ precipitation infiltration and no effective runoff produced) to 100 (where there's 0.33 precipitation infiltration and high effective runoff is produced). Curve number with low values indicates low runoff potential, whereas curve number with high values represents high runoff potential [15]. The curve number was calculated per every pixel using the combined land cover, slop map and soil maps as input factors. This curve number characterizes the runoff properties of those three layers combined for each basin.

$$
Q=P-I a 2 / P-I a+S
$$

where:

Q: runoff depth (mm)

$P$ : rainfall (mm)

$S$ : potential maximum retention after runoff starts $(\mathrm{mm})$

Ia: initial abstraction $(\mathrm{mm})$

Ia: $0.2 S$

Potential maximum retention $(S)$ can be calculated by the Curve Number as:

$$
S=25400 / \mathrm{CN}-254
$$

The $\mathrm{CN}$ for the study area values were within the range 72 - 85 (Figure 5).

\subsection{Surface Runoff}

Surface runoff (also called land flow) is the flow of water that takes place once excess storm water, melt water, or different sources of flow over the earth's surface. This occurs as a result of soil saturation to full capacity. Surface runoff is a major part of the water cycle. It's the primary agent in land erosion by water [16]. 


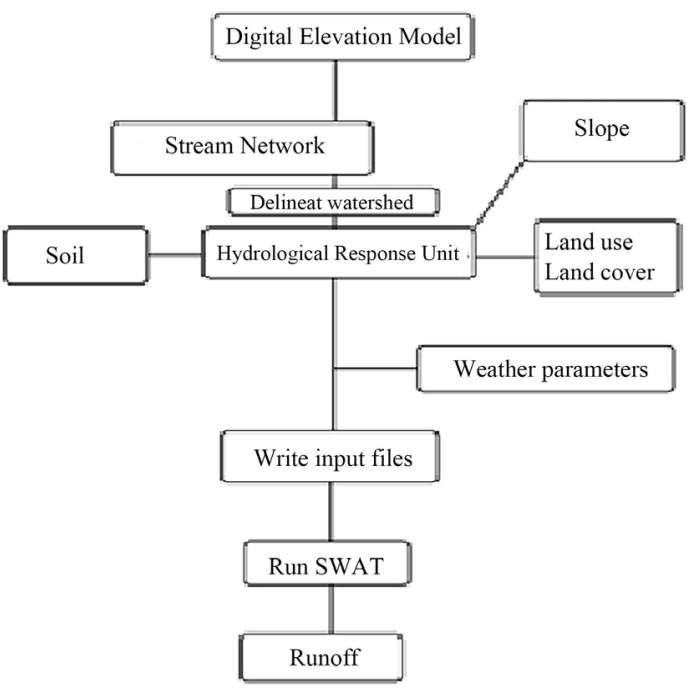

Figure 4. SWAT model.

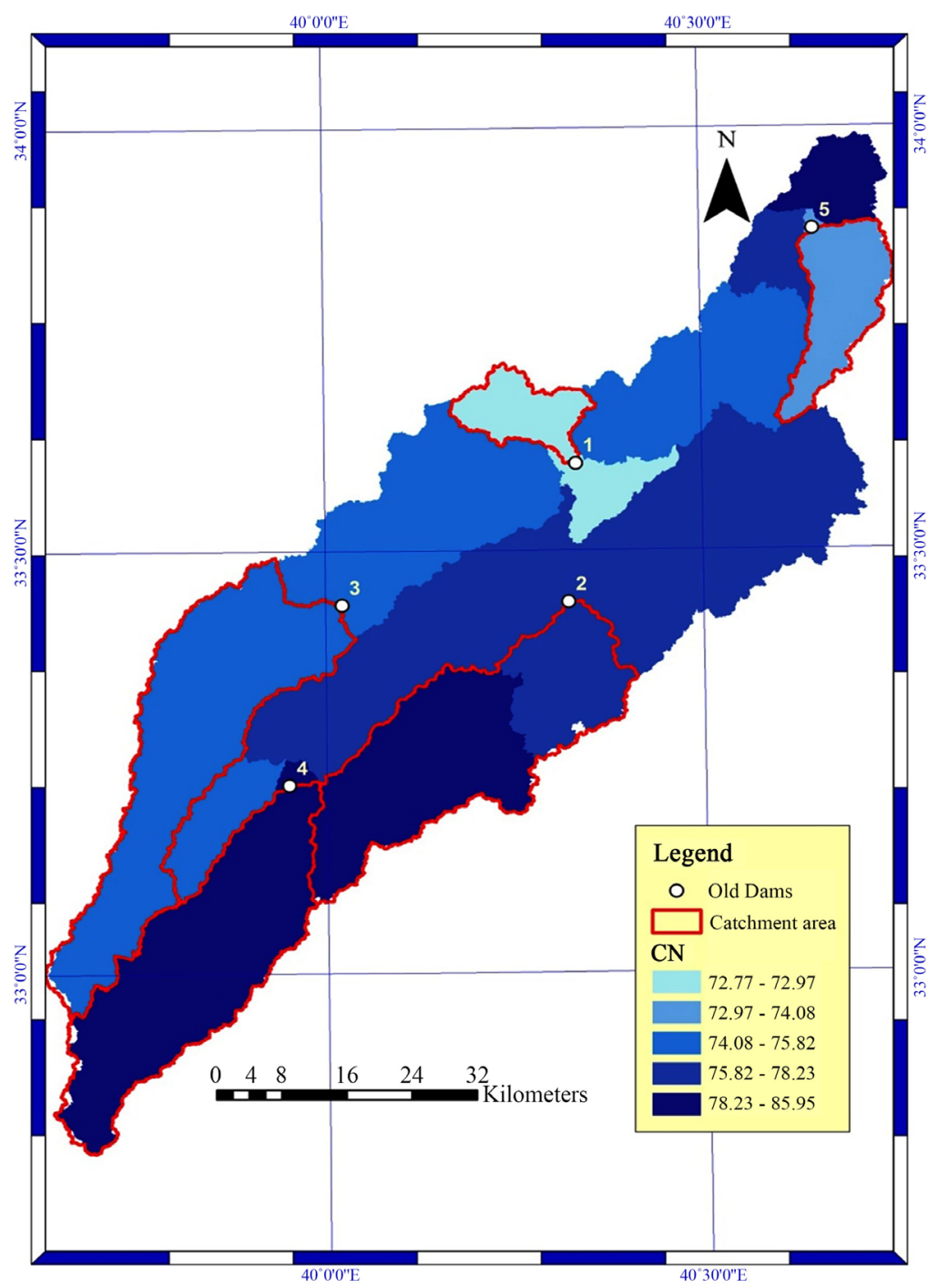

Figure 5. CN distribution of study area. 
The physical factors affecting runoff are: land use, vegetation, soil type, drainage area, basin shape, elevation slope, topography, direction and orientation, drainage network patterns and reservoirs, in the basin, which prevent or alter runoff from continuing downstream.

Knowing the runoff for study area helps to guess the volume of water for each dam (Figure 6).

\subsection{Volume of Harvested Water}

Through the results (Table 1) taken from the SWAT tool to calculate runoff for each dam's catchment area and through the use of the Equation (3) water quantities were calculated as:

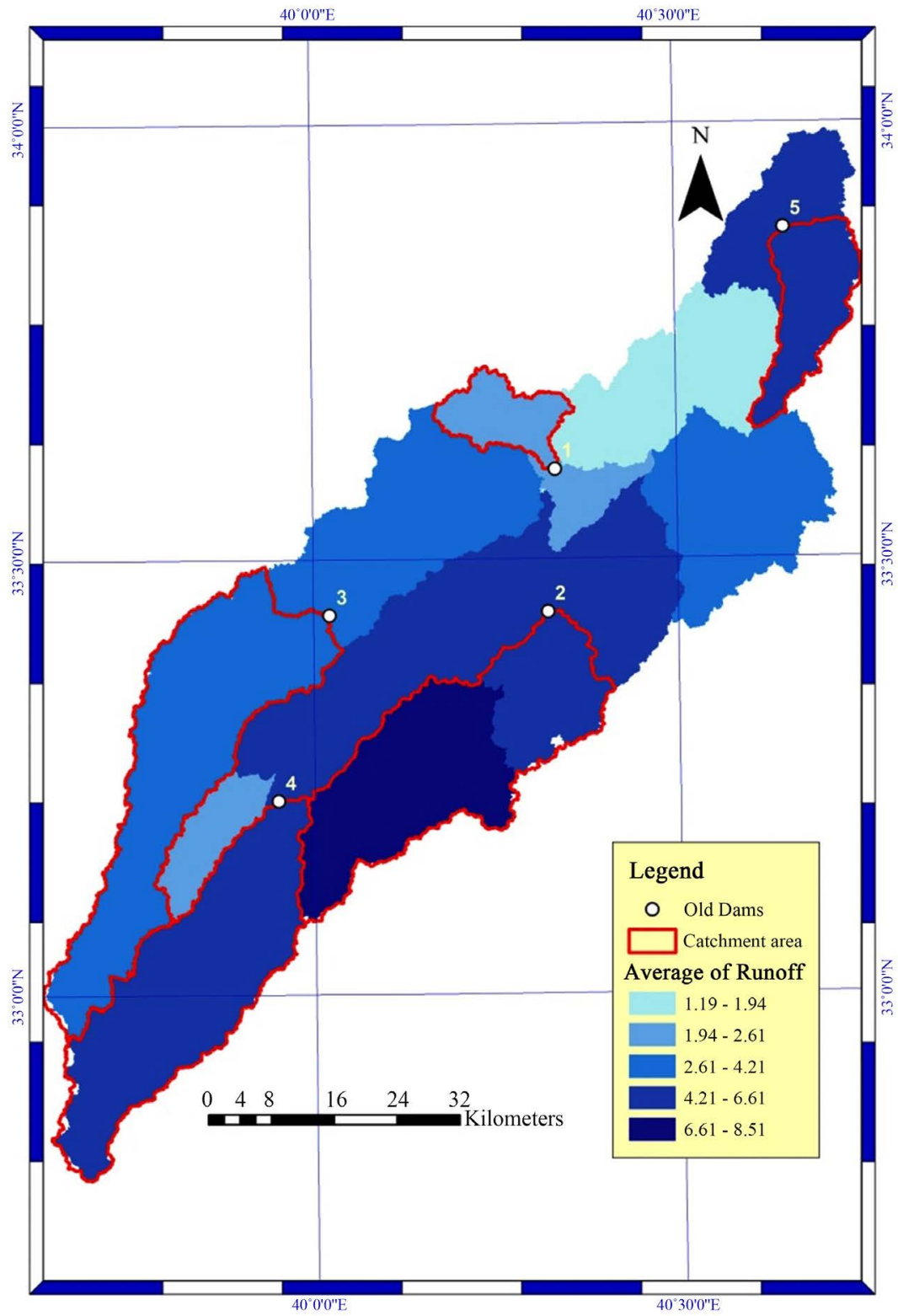

Figure 6. Distribution of the average values of surface runoff of the study area for the period 1994-2014. 
Table 1. The results of the calculations of the quantities of water expected for each dam.

\begin{tabular}{ccccc}
\hline Dam No. & Area $\left(\mathrm{m}^{2}\right)$ & $\begin{array}{c}\text { Maximum } \\
\text { Runoff Vol. } \\
2014\left(\mathrm{~m}^{3}\right)\end{array}$ & $\begin{array}{c}\text { Minimum. } \\
\text { Runoff Vol. } \\
2009\left(\mathrm{~m}^{3}\right)\end{array}$ & $\begin{array}{c}\text { Average. } \\
\text { Runoff Vol. } \\
(1994-2014) \\
\left(\mathrm{m}^{3}\right)\end{array}$ \\
\hline Dam 1 & $118,038,000$ & 826,266 & 30.6899 & 249,886 \\
Dam 2 & $655,393,000$ & $16,140,353$ & 129.6 & $4,824,400$ \\
Dam 3 & $673,419,000$ & $9,629,890$ & 107.747 & $2,839,810$ \\
Dam 4 & $622,343,000$ & $9,210,680$ & 80.9046 & $3,796,290$ \\
Dam 5 & $192,281,000$ & $7,114,400$ & 16151.6 & $1,272,710$ \\
\hline & & $V$ & &
\end{tabular}

where:

$$
\begin{aligned}
& V=\text { Annual runoff volume }\left(\mathrm{m}^{3}\right) \\
& Q=\text { Annual runoff }(\mathrm{mm}) \\
& A=\text { Drainage basin area }\left(\mathrm{m}^{2}\right)
\end{aligned}
$$

\subsection{Suitability Map for RWH}

Identification of suitability map for water harvesting needs a multiple data from different sources which should be used in the geographic information system techniques to get the best results. Each watershed has various physiographic characteristics of the study area such as slope, rainfall, land use/land cover, soil, drainage density \& drainage pattern. These were integrated with the use of remote sensing and GIS techniques to understand the characteristics of the watershed and its runoff flow pattern whether it is high or low. On the basis of interpretation the best Water harvesting sites are to be found [17] (Figure 7).

All processes in the creation of a suitable rainwater harvesting map were applied during a convenience model developed in Arc GIS 10.3. The model creates rainwater harvesting compatibility map by merging totally different criteria employing a weighted combination process [6]. This model includes the standardization of appropriateness maps, the weighting of the comparative significance of appropriateness maps, and also the merging of weights and uniformity maps to realize a suitability value [18]. The model is based on the conception of weighted averages, and it's prepared by multiplying the weight of the factor by its consistent membership score (Equation (4)):

$$
S=\sum W i X i
$$

where $S$ : suitable site, $W i$ : weighting of factor $i$, and $X i$ : the membership value of criteria $i$.

According to the weight of the factors, the results showed four classes for suitable water harvesting site. The map shows all dams built within the study area in high suitability class. 


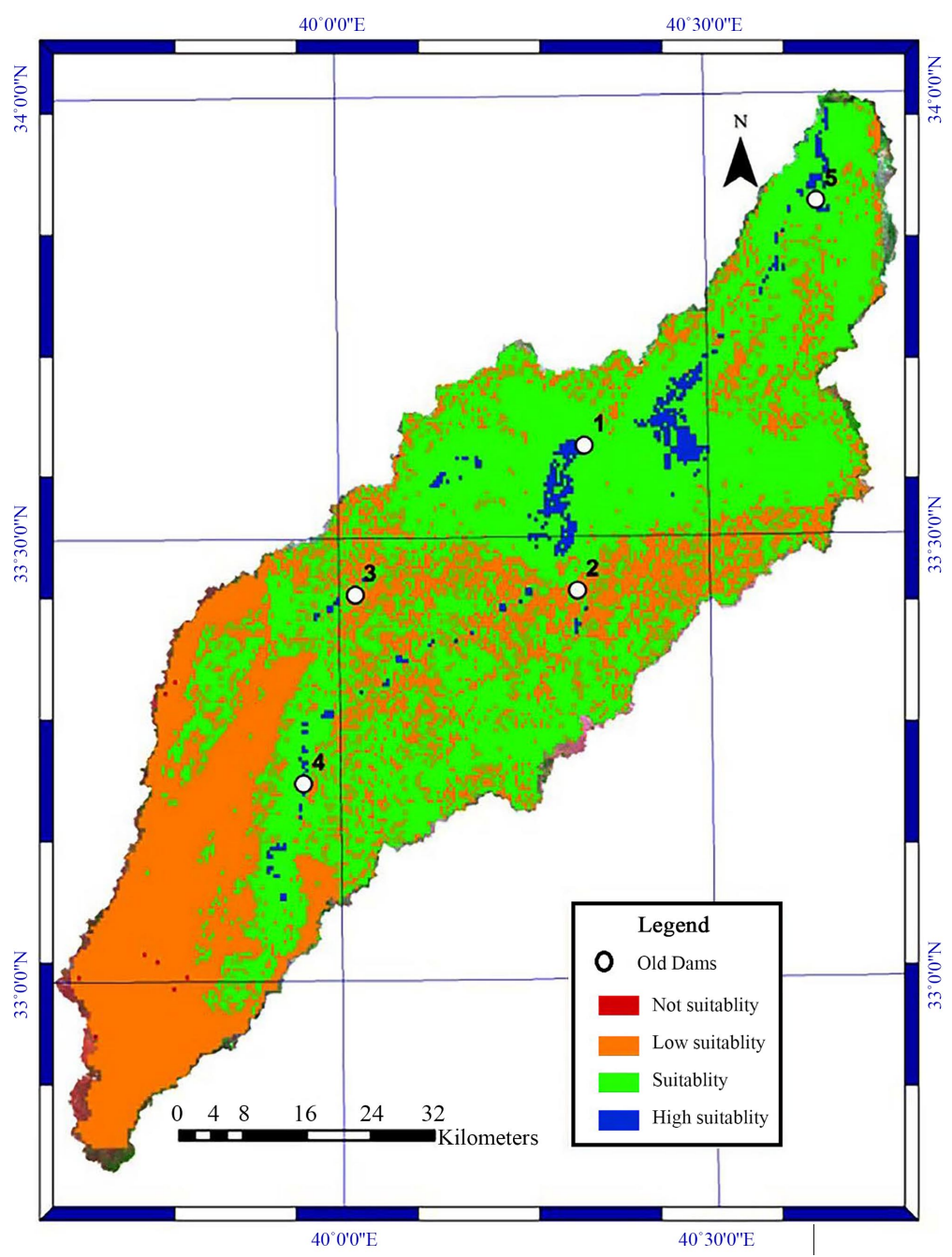

Figure 7. Suitability map for water harvesting of study area.

After identifying the suitability map for rain water harvesting, which were consistent with necessary criteria taken under consideration. FAO standards for water harvesting dams were taken in terms of proximity to agricultural areas and roads for evaluating dams established in the study area. A site that was less than $0.5 \mathrm{~km}$ distance to agricultural activities was considered appropriate for the dam site. The distance to agricultural activities was very small so as to have access to water for farming purposes and close to the roads to provide enough access to the route networks [19] (Figure 8 and Figure 9). The results indicate that dam number one is within the appropriate category while the rest of the dams are within the category inappropriate for distance from agricultural areas. As for the distance from the roads, the results show that dams number one and four within a highly appropriate category The rest of the dams are classified as inappropriate (Table 2).

\section{Results and Discussion}

Five old dams were identified using land $\mid$ water index Bands (5-6-4). The Curve 
Number for the study area values were within the range $72-85$ and runoff rate (1.2 - 8.2) $\mathrm{mm}$ for the period (1994-2014). This has been identified using SWAT

Table 2. Appropriateness for dam's site.

\begin{tabular}{cccccc}
\hline Dam No. & Land suitability & $\begin{array}{c}\text { Distance to } \\
\text { Agricultural } \\
\text { lands }(\mathrm{Km})\end{array}$ & Appropriateness & $\begin{array}{c}\text { Distance to } \\
\text { roads (Km) }\end{array}$ & Appropriateness \\
\hline 1 & High suitability & 1264 & Suitable & 1774 & High suitable \\
2 & High suitability & 13,084 & Not suitable & 19,748 & Low suitable \\
3 & High suitability & 20,779 & Not suitable & 14,811 & Low suitable \\
4 & High suitability & 44,482 & Not suitable & 1807 & High suitable \\
5 & High suitability & 22,994 & Not suitable & 30,506 & Not suitable \\
\hline
\end{tabular}

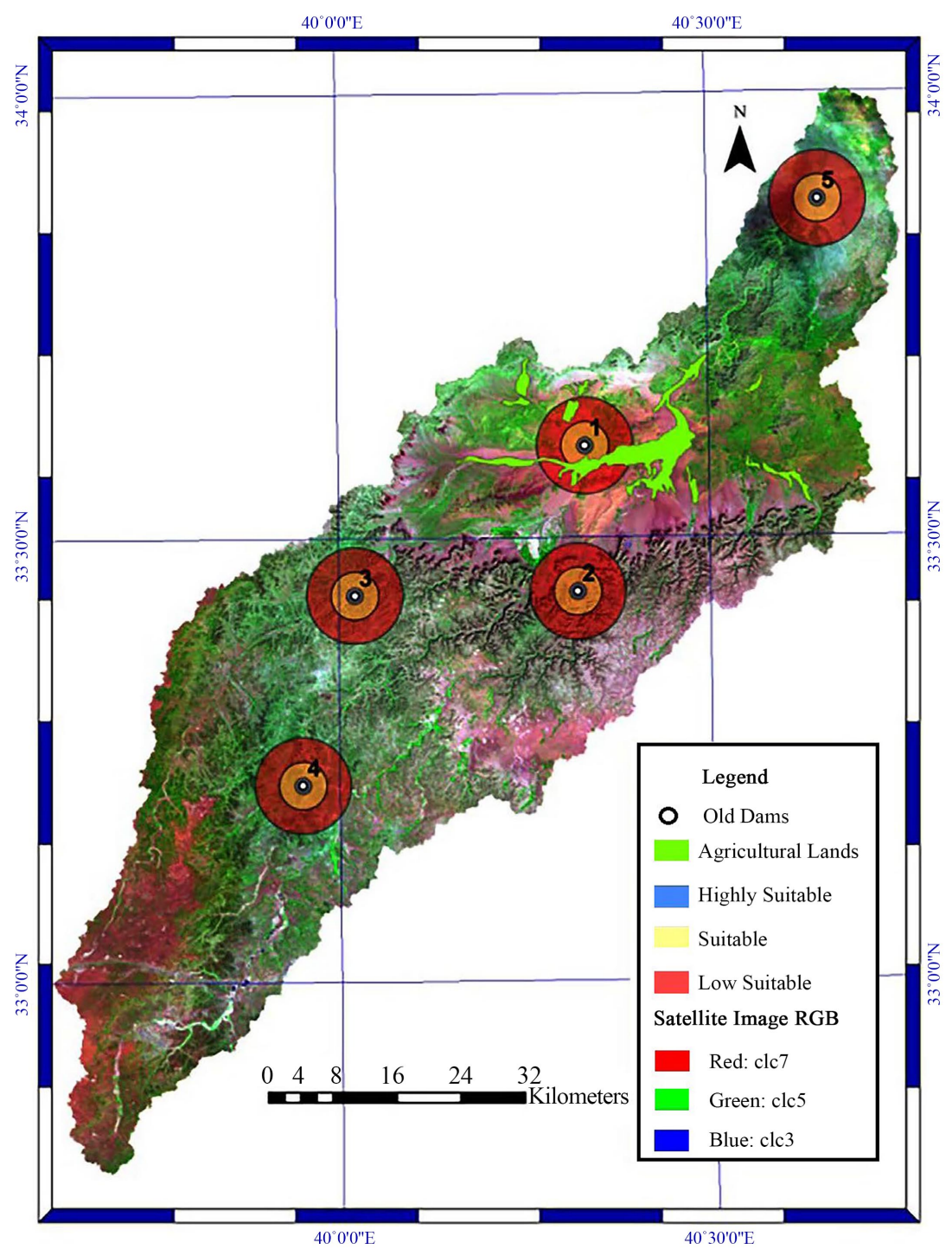

Figure 8. The appropriate distance to agricultural lands. 


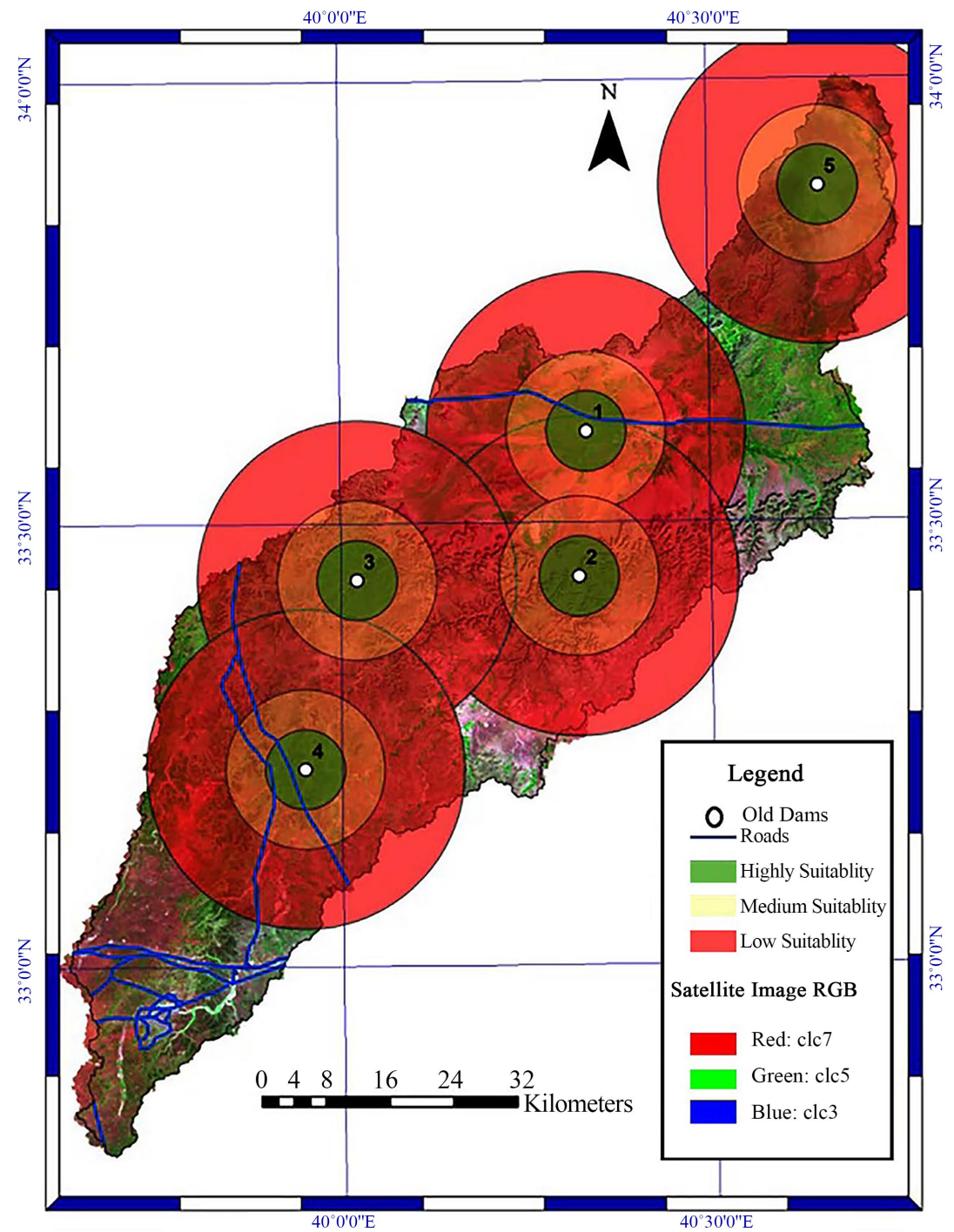

Figure 9. Appropriate distance to roads.

model. Using the Arc Hydro, the catchment area for each dam was determined which was (dam 1: 118.038, dam 2: 655.393, dam 3: 673.419, dam 4: 622.343, dam 5: 192.281) $\mathrm{Km}^{2}$. The average water volume collected for dams from the period 1994 to 2014 ranged was within the range 249,886 to $4,824,400 \mathrm{~m}^{3}$.

These dams were assessed by establishing a map suitability for the water harvesting sites. The elements affecting water harvesting were taken: rainfall, soil hydrology texture, drainage density, slope, and land use/cover, by weighting of these factors in GIS the results showed that, four classes for suitable water harvesting site. All dams built were within the study area in high suitability class.

Although all the dams are within the classification high suitability, but the results when compared relative to FAO standards for the distance of dams from agricultural areas using GIS showed that all dams appropriateness were not suitable except dam number (1). The distance to roads showed that, dams $(1,4)$ are high suitability, $(2,3)$ are low suitability and dam (5) is not suitable. 
The inadequacy of the distance between the dams for harvesting and the agricultural areas leads to a weakness in the desired goal of establishing these dams due to the loss of large quantities of water and the difficulty of establishing irrigation systems.

Inadequate distance between dams and roads increases the cost of building and maintaining these dams. On the other hand, the study area faces security risks, and the far distance between dams and roads leads to an increase of these risks to these facilities and their workers.

\section{Conclusions}

To test the validity of dams constructed for rain water harvesting technique, the dams that exist in an area within the desert in Iraq was studied. This was achieved using SWAT model, remote sensing and ARC GIS techniques. Five dams were studied thoroughly and the main outcomes of this study were:

- Five old dams were identified Using land।water index Bands (5-6-4);

- The Curve Number for study area values were within the range $72-85$ calculated by SWAT tool. This causes low infiltration;

- Runoff rate was (1.2 - 8.2) $\mathrm{mm}$ for the period 1994-2014;

- The average annual quantity of rain water that can be harvested from the 5 dams is about 12.9 million cubic meters;

- All dams built within the study area in high suitability class;

- The results relative to FAO standards for the distance of dams from agricultural areas using a GIS showed that all dams' appropriateness was not suitable except dam number (1);

- The distance to roads showed that dams $(1,4)$ in high suitability, $(2,3)$ in low suitability and dam (5) is not suitable.

\section{Conflicts of Interest}

The authors declare no conflicts of interest regarding the publication of this paper.

\section{References}

[1] Al-Ansari, N. (2019) Hydro Geopolitics of the Tigris and Euphrates. In: Mustafa, Y., Sadkhan, S., Zebari, S. and Jacksi, K., Eds., Recent Researches in Earth and Environmental Sciences. Springer Proceedings in Earth and Environmental Sciences, Springer, Cham, 35-70. https://doi.org/10.1007/978-3-030-18641-8_4

[2] Al-Ansari, N.A., Ali, A. and Knutsson, S. (2014) Present Conditions and Future Challenges of Water Resources Problems in Iraq. Journal of Water Resource and Protection, 6, 1066-1098. https://doi.org/10.4236/jwarp.2014.612102

[3] Zakaria, S., Al-Ansari, N.A., Dawood, A.H. and Knutssson, S. (2014) Future Prospects for Macro Rainwater Harvesting Technique at Northwest Iraq. Journal of Earth Sciences and Geotechnical Engineering, 4, 1-16.

[4] Al-Sheikh, A.A. (2006) Harvesting Rainwater and Floods and Its Importance to Water Resources Saudi Arabia. 2nd International Conference on Water Resources and Arid Environment, Riyadh.

[5] Ziadat, F.M., Mazahreh, S.S., Oweis, T.Y. and Bruggem, A. (2006) A GIS Based Ap- 
proach for Assessing Water Harvesting Suitability in a Badia Benchmark Watershed in Jordan. 14th International Soil Conservation Organization Conference. Water Management and Soil Conservation in Semi-Arid Environments, Marrakech, Morocco, 14-16 May 2006.

[6] Malczewski, J. (2004) GIS Based Land Use Suitability Analysis: A Critical Overview. Progress in Planning, 26, 3-65. https://doi.org/10.1016/j.progress.2003.09.002

[7] Al-Adamat, R., Al-Ayyash, S., Al-Amoush, H., Al-Meshan, O., Rawajfih, Z., Shdeifat, A. and Al-Farajat, M. (2012) The Combination of Indigenous Knowledge and Geo-Informatics for Water Harvesting Sitting in the Jordanian Badia. Journal of Geographic Information System, 4, 366-376. https://doi.org/10.4236/jgis.2012.44042

[8] Al-Abadi, A.M. (2012) Hydrological and Hydro Geological of Analysis of Northeastern Missan Governorate, South of Iraq Using Geographic Information System. College of Science, Baghdad University, Baghdad.

[9] Sissakian, V.K. and Mohammed, B.S. (2007) Stratigraphy of the Iraqi Western Desert. Geology of Iraqi Western Desert, 51-124.

[10] Balasubramanian, A. (2017) Digital Elevation Model (DEM) IN GIS. Centre for Advanced Studies in Earth Science, University of Mysore, Mysore.

https://www.slideshare.net/bala1957/digital-elevation-model-in-gis

[11] Adham, A., Riksen, M., Ouessar, M. and Ritsema, C. (2016) Identification of Suitable Sites for Rain Water Harvesting Structures in Arid and Semi-Arid Regions, a Review. International Soil and Water Conservation Research, 4, 108-120. https://doi.org/10.1016/j.iswcr.2016.03.001

[12] Neitsch, S.L., Arnold, J.G., Williams, J.R., Kiniry, J.R. and King, K.W. (2011) Soil and Water Assessment Tool Theoretical Documentation Version 2009. Texas Water Resources Institute, Technical Report No. 406, TX.

https://swat.tamu.edu/media/99192/swat2009-theory.pdf

[13] Panagopoulos, Y., Dimitriou, E. and Skoulikidis, N. (2019) Vulnerability of a Northeast Mediterranean Island to Soil Loss Can Grazing Management Mitigate Erosion. Water, 11, 1-20. https://doi.org/10.3390/w11071491

[14] Gupta, K.K., Deelstra, K. and Sharma, D. (1997) Estimation of Water Harvesting Potential for a Semiarid Area Using GIS and Remote Sensing. Remote Sensing and Geographic Information Systems for Design and Operation of Water Resources Systems, Rabat Symposium S3, 53-62.

[15] Melesse, A.M. and Shih, S.F. (2002) Spatially Distributed Storm Runoff Depth Estimation Using Landsat images and GIS. Computers and Electronics in Agriculture, 37, 173-183. https://doi.org/10.1016/S0168-1699(02)00111-4

[16] Beven, K. (2004) Robert E. Horton and Abrupt Rises of Ground Water. Hydrological Processes, 18, 3687-3696. https://doi.org/10.1002/hyp.5741

[17] Prasad, H., Bhalla, P. and Palria, S. (2014) Site Suitability Analysis of Water Harvesting Structures Using Remote Sensing and GIS-A Case Study of Pisangan Watershed, Ajmer District, Rajasthan. The International Archives of the Photogrammetry, Remote Sensing and Spatial Information Sciences, XL-8, 1471-1482. https://doi.org/10.5194/isprsarchives-XL-8-1471-2014

[18] Al-Hanbali, A., Alsaaideh, B. and Akihiko, K. (2011) Using GIS-Based Weighted Linear Combination-Analysis and Remote Sensing Techniques to Select Optimum Solid Waste Disposal Sites within Mafraq City, Jordan. Journal of Geographic Information System, 3, 267-278. https://doi.org/10.4236/jgis.2011.34023

[19] Boateng, B., Stemn, E. and Sibil, S. (2016) Multi-Criteria-GIS Based Site Selection for Irrigational Reservoir-A Case Study. European Agrophysical Journal, 3, 1-17. https://doi.org/10.17830/j.eaj.2016.03.001 